\title{
5. Conflict and Agreement: The Politics of Nickel in Thio, New Caledonia
}

PIERRE-YYES LE MEUR ${ }^{1}$

\section{Introduction}

In late July 1996, the entrances to Plateau and Camps des Sapins, the two main mines in Thio, were blockaded by the commune's Kanak inhabitants. Blockades were also placed on the ore transfer belt in nearby Thio Mission and on a Japanese ore carrier, the Tango Gracia, which was in the process of being loaded by its Filipino crew. The stand-off between the Thio coutumiers ('customary representatives') and the company Société Le Nickel (SLN) lasted two weeks and culminated in a wide-ranging written agreement which, despite being local in scope, went beyond the context of work and touched on environmental and social issues, the question of the control of resources, and the redistribution of mining revenues (see Filer 1997; Bainton 2009).

1 This study was carried out as part of a research program financed by the National Centre for Technological Research, under the title 'Nickel Politics between Local Governance and Corporate Governance: The Comparison of Mining and Industrial Development in New Caledonia'. I should like to sincerely thank Jean-Michel Sourisseau for his critical and constructive reading of an initial version of this text, and Susan Cox for translating it into English. 
Thio, a commune located on the east coast of South Province, was the country's 'nickel capital' for a long time, and SLN, which was established in 1880 and based in Thio during the interwar period, enjoyed a dominant position in the production and processing of nickel in New Caledonia. ${ }^{2}$ The town of Thio was also one of the focal sites of les événements ('the events'), a period of violent clashes between 1984 and 1988 that combined elements of civil war between the Kanak separatists and New Caledonian loyalists with the Kanak decolonisation struggle, so the location and protagonists in this particular tale are not without significance. Equally significant is the unfolding of this social movement - the blockade itself, the willingness to extend or escalate the conflict beyond the boundaries of the mine site and then the eventual agreement. Finally, the discursive structure of this conflict as a conflit des coutumiers also merits some explanation.

I shall start from the hypothesis that this conflict and the resulting agreement mark a turning point in local mining governance. This chapter will describe the configuration of actors, issues and discourses involved in the conflict, and will situate it in the previous history of local conflicts and in relation to the changes in mining affairs and the political situation in New Caledonia in the 1980s and 1990s. I shall then analyse the reconfigurations of the local arena prompted by the conflict negotiations from three perspectives. The first is that of landownership, specifically the contest between the political (or historical) and legal recognition of land rights. The second is that of politics - the redefinition of affiliations and locality, the reorganisation of chieftainship and the positioning of the town hall. The third is that of business, involving questions of subcontracting, local employment and business development. ${ }^{3}$

2 This monopoly was toppled in the 2000 s, particularly in 2010 , with the establishment of two new mining and industrial projects in the north and south of the island (see Chapters 2, 3 and 6 , this volume).

3 The analysis is based on retrospective interviews carried out in Thio between 2008 and 2014, and on various documentary sources: newspaper articles published in Les Nouvelles Calédoniennes between 26 July and 7 August 1996; minutes of the consultation meeting of 9 August 1996; the text of the protocol to the agreement of 6 August 1996; the letter sent on 18 October 1996 by the presidents of the two districts of Thio (Philippe Nekaré and Charles Moindou) to the government delegate, Dominique Bur, and the chief executive of SLN, Jean-Jacques Mouradian, through JeanMichel Arlié, Deputy Commissioner of South Province, requesting compensation for the land washed away or polluted through the activities of SLN in light of the earlier agreement; the letter sent by the sous-préfecture (subdivision) to the deputy commissioner on 30 October 1996; a letter sent by the deputy commissioner to the chief executive of the Agency for Rural Development and Regional Planning; and other correspondence and minutes of follow-up meetings relating to the August agreement. 


\section{The Conflict and the Agreement}

\section{The Conflict-Based Approach}

The heuristic productivity of the conflict-based approach has long been acknowledged, in particular since the work of Max Gluckman, Victor Turner and other members of the 'Manchester School' (see Turner 1957). No society is exempt from conflict, so it constitutes a general empirical phenomenon. Conflicts constitute moments in time that crystallise and highlight opposing positions; they do not emerge haphazardly. They constitute spaces for the expression of arguments or registers of justification (revealing judgments, knowledge and information) that tend to 'harden' and gain in visibility over the course of a dispute. Finally, conflicts are not simply 'revealing' in the photographic sense of representing a preexisting sociopolitical topography; they are factors that reconfigure the rules of a game-mining governance in the case in point - and therefore constitute factors of institutional change. They are part of broader sequences of events that include their modes of resolution (in this case a written agreement), as well as measures of avoidance or patterns of re-emergence. Moreover, and in relation to the context of New Caledonia, disputes like that under consideration here are part of a long-term process, that of the consubstantial 'meta-conflict' of settler colonialism. We shall see clearly how this historical legacy is inscribed in the manner in which the question of landed property is negotiated. In this sense, conflicts fulfil a function, even if it is not that ascribed to them in advance. The point of view adopted here is processual and not functionalist, and leaves open the specific empirical question as to whether this was a conflict 'about' the control of resources, or whether control of resources became the pretext for a conflict about other things.

We can take inspiration here from the suggestions made by Glenn Banks in his analysis of mining conflicts in Papua New Guinea (Banks 2008). Banks stresses the overlaps between questions surrounding resources and affiliations and the continuity of a sociopolitical order. Secondly, he highlights their processual dimension: what is involved in most cases is the restoration of a balance rather than the regulation of a situation in the strict sense-in other words, a question of 'peace' rather than 'justice', to use the terms employed by Sten Hagberg in a completely different context (Hagberg 1998). Along the same lines, the compensation eventually paid is more 'relational' than 'transactional' in nature and, more often than 
not, the requested and/or self-appointed mediators are interested and involved in the conflict arena, as opposed to being neutral and external, as would be desirable in a 'United Nations' style of mediation. Banks proposes, thirdly, that mining conflicts are both strongly embedded at a local level-in terms of actor configurations and normative repertoiresand marked by, or the products of, the exogenous rupture constituted by the precipitous development of the mining project, as tragically shown in the case of the Panguna copper mine in Bougainville (Regan 1998, 2014; see also Allen 2013 and Chapter 12, this volume). I argue that this rupture is expressed in a tension between inflows (of actors, material and immaterial resources) and a 'normative gap' that derives from failure to establish the 'rules of the game' in the early stages of mining projects. This tension, which should be viewed relative to the historicity of mining activity in a given location, is a powerful driver of conflict. It could also be argued that mining conflicts question the boundaries of the company, as an entity located on the interface between corporate governance and local arenas, and the enclave logic that inherently underlies a mining operation. The company is formed through the definition of a physical, institutional and ideological action perimeter-the 'inside' and 'outside' (or externalities) of the company-and this perimeter is contested by certain actors. ${ }^{4}$

\section{The Context}

The context in which this localised conflict arose was that of the sequence of les événements and the resulting political agreements-the MatignonOudinot Agreements in 1988, the Nouméa Agreement in 1998-the latter marking the advent of an original negotiated process of decolonisation. The context is also that of the increasing significance of mining as an issue, which the pro-independence parties placed at the heart of the political debate in the 1990s, resulting in the negotiation of a préalable minier ('mining prerequisite') in the Bercy Agreement of February 1998. ${ }^{5}$

4 On the different forms of industrial pollution (e.g. 'spillage' versus 'overflow'), see Letté (2009). On the notion of the mining enclave, see Le Meur et al. (2013) and Allen (2017).

5 The signature of the Bercy Agreement as a 'mining prerequisite' to the Nouméa Agreement of 1998 , which prompted the initiation of a process of negotiated decolonisation in New Caledonia, should not be seen retrospectively as the start of a harmonious and linear process. Its roots go back further, to the nationalisation of the Société Minière du Sud Pacifique in 1990. Debates among separatists on the opportunity to start thinking in capitalist terms were tempestuous, and the story of the appropriation of the issue of mining by the pro-independence groups was yet to unfold. I thank Jean-Michel Sourisseau for drawing my attention to this point (see also David et al. 2016: 33-39). 
This was followed by the arrival of the mining multinationals in the 2000 s and the rise of environmental and indigenous rights discourses. In this regard, the conflict of 1996 may be seen as 'pre-indigenous rights' and, as we shall see, represents a turning point in relation to a number of issues - mining, land, indigeneity, customary authority, and so forth (see Chapters 4 and 6, this volume).

\section{The Story}

The conflict of 1996 started with a lockout that would last for 13 days. The lockout was not the only form of expression used; it was also accompanied by written documents. On 25 July, a package of demands (cahier de revendications), signed by representatives of the two customary districts of Thio (Thio and Borendy), ${ }^{6}$ was submitted to SLN, to the High Commissioner of the Republic (the representative of the French central state in New Caledonia), to South Province and to the parties represented in the Congress of New Caledonia 'because, according to the customary authorities, the demands concern all of the partners' (Huillet 1996a). The package of demands was divided into eight sections relating to: (1) recruitment; (2) the granting of mining licences by SLN to the customary authorities; (3) subcontracting, with a demand that Nouméan companies establish offices in Thio; (4) assignment to the commune of the Baie de la Mission housing development scheme (the issue had been blocked for three years); (5) the restitution of land and compensation for arable areas; (6) the establishment of an anti-pollution team at the mine; (7) financing for rehabilitation of environmental damage caused by the operation; and (8) the creation of infrastructure that would 'open up' the commune.

A meeting was held in Thio on 29 July 1996 with a view to negotiating these demands. The leaders of the movement rejected an offer by SLN to transfer the meeting to its headquarters in Doniambo, near the Nouméa processing plant. They demanded that the meeting be held in the open air, on 'their land', on the access road to the Plateau mine.

6 The organisation of indirect colonial government through the administrative chieftaincy was gradually established with the creation of the 'tribe' in 1867, the chieftaincy ('petit chef, that is, 'little chief' or tribal chief) in 1868, the institution of the régime de l'indigénat ('indigenous legal code') in 1887, and the district headed up by the 'grand chef' ('big chief') in 1897. The transfer of the Kanak population to reservations was carried out progressively during the same period, and was systematised with the grand cantonnement at the turn of the twentieth century under Governor Feillet (see Dauphiné 1987; Merle 1998, 2004). 
On 6 August 1996, an agreement was signed at the La Foa souspréfecture ('subdivision') office between SLN, the commune of Thio, and the two councils of the customary districts of Thio. The agreement basically constituted a response to the grievances outlined in the package of demands presented in July, and included:

- provisions for the resettlement of people located in the flood zone, based on the argument that the mining slag heaps had caused the silting up of the Thio River;

- provision by SLN of insurance policies to local farmers to cover the eventuality of damage to their crops; and

- the possibility of quadripartite mediation between the state, the commune, SLN and the two customary districts in cases of dispute.

Another meeting was held at the town hall on 9 August, following hot on the heels of the signing of the agreement. The agenda for this meeting also referred to the package of demands and the terms of the agreement. However, rather than focusing on questions directly related to the mine-recruitment, mining licences, subcontracting - it highlighted, in particular, the issues of land use planning, residential development and land redistribution. A monitoring committee was established and was active for around a decade, particularly in relation to the recruitment of the inhabitants of Thio. However, the mining licence took a long time to materialise. The new Kanak mining company, Société Minière des Kanak de Thio (SOMIKAT), was established in 2007 and commenced production in 2010 (Seyrane Belliot and Léopold Gnahou, interviews, 29 March 2012).

The blockades were not located in the operational area of the mine, and there was no occupation of mining sites or offices as is often the case in labour conflicts. In this instance, the theatre of the conflict-which was not a traditional labour conflict-shifted towards the interfaces and thresholds between the town and the mine (the entrance to the Plateau and Camp des Sapins mines) and between the town and the outside world (the wharf). The locations of the negotiations were also carefully selected: under no circumstances would they be held on SLN ground, whether in Thio or at the headquarters in Nouméa. The protesters insisted that they be held on the territory of the native inhabitants, that is, in front of the mine, at the town hall, which had been under the control of the pro-independence Front de Libération Nationale Kanak et Socialiste (FLNKS) since 1986, or in the subdivision, in the 'house of the state'. 
Some of the actors involved in the conflict, and some people who were still children at the time, recall the atmosphere in those two weeks as being rather festive and non-violent. Seyrane Belliot, the manager of SOMIKAT (until 2014), remembers playing with her friends amongst the adults, in a joyful hubbub involving political debates and barbecues in front of the entrance to the mine (interview, 19 November 2012). ${ }^{7}$ At the same time, women from the tribes at the lower end of Thio worked in shifts to prepare meals for the blockaded Filipino sailors on their ore carrier, who were beginning to run out of supplies. ${ }^{8}$

The choice of the locations and the declarations of the local leaders express the same desire for access and opening up: it was about getting away from the usual form of confrontation with SLN, which always tried to resolve problems through the adoption of a private, bilateral logic of compensation. ${ }^{9}$ While condemning the lack of environmental awareness on the part of SLN, and the devastating effects of this negligence on the landscape of the commune, the customary leaders insisted that this state of affairs was equally the concern of 'all parties', that is, all politicaladministrative levels of organisation. This strategy of 'publicising' the conflict leads us to the identification of the actors involved, and hence also to pinpointing important absences.

\section{Actors and Absences}

First, it is clear that the customary representatives were the driving force behind the process. The individuals in question were the two major chiefs, Damas Toura (Thio) and Philippe Nekaré (Borendy), who both enjoyed significant historical and 'customary' legitimacy beyond their positions as administrative chiefs, who were current or former employees of SLN, and who belonged to the loyalist political party, the Rassemblement pour la Calédonie dans la République, like the chief of Kouaré, Moïse Mapéri,

7 Seyrane's mother, Ithupane Tiéoué, a PALIKA militant and, at the time, secretary to the mayor of Thio, completely concurred with this account (interview, 26 November 2010).

8 The tension was clearly palpable at times - this was also an argument used in the negotiationsbut it is astonishing to note the extent to which the accounts provided in the anti-independence local daily newspaper Les Nouvelles Calédoniennes are partial in this regard, and insist solely and vehemently on the 'tension that emanates from the strikers. A machete, a club or a rock in their hands, they guard the road blockade and rise to meet the least approach from outside' (Huillet 1996a). The 'primitivist' tone of this account (e.g. the 'club') is noteworthy.

9 This had been the typical company response to all claims for damages, be it that involving the Thio Mission during the interwar period (Winslow 1993), or later involving European livestock breeders (R. Lacrose, interviews, 28 August and 11 September 2008). 
who was also active in the process. However, the leading personality in the conflict was Charles Moindou, the president of the district council of Thio, and also an active member of the Union Progressiste Mélanésienne (UPM), which was part of the pro-independence FLNKS alliance established in 1984. He and his two brothers, Joseph and Albert, ${ }^{10}$ formed a group with considerable accrued political and economic capital as members of the UPM, even though some people contested the legitimacy of their positions as customary leaders.

SLN was involved through its office in Thio, the governance of which was - and still is - based on a pairing formed by the head of the office, generally a metropolitan 'expatriate', and the human resources manager, who was normally integrated into the local social fabric, or at least of New Caledonian origin, though not actually a member of the mineaffected community.

The central or 'metropolitan' state was represented by the deputy commissioner (commissaire délégué) of South Province and, less directly, by three government departments-the Agence de Développement Rural et d'Aménagement Foncier, the Direction des Infrastructures, de la Topographie et des Transports Terrestres and the Direction du Développement Rural (the last two being part of New Caledonia's territorial administration). ${ }^{11}$

Two other groups of actors may be characterised in more sociological terms. First, the town hall played the role of the 'political-state intermediary' due to its pivotal position as the bottom rung of the state apparatus and its elected leadership, especially as it had been taken over by the pro-independence FLNKS alliance after les événements. ${ }^{12}$ In addition to the town hall, which would remain a rather secondary force in the process, two men were chosen as official spokespersons by the customary leaders-Amédée Tiéoué and

10 Joseph was an elected representative of the FLNKS in South Province from 1989 to 1995. Albert would become the mayor of Thio in 2001.

11 New Caledonian usage tends to equate the 'state' with the government of France, neglecting the fact that it contains different levels of political organisation, especially in the New Caledonian context, where the three provinces (South, North, Islands) established by the Matignon-Oudinot Agreements of 1988 enjoy wide-ranging powers, in particular with respect to economic development and the environment. The Nouméa Agreement of 1998 installed a collegial government at the level of the territory of New Caledonia, and the territorial congress, elected through indirect suffrage by the provincial assemblies, has its own legislative powers.

12 The current mayor, Louis Mapéri, was a member of the Parti de Libération Kanak (PALIKA), who had been elected to replace the former mayor, Roger Galliot, after a year-long period of municipal subjection to central state control. 
Joseph Moindou (the brother of Charles). Both of them belonged to economically influential families, and in 1982 had been co-founders of UNICONCEQ, one of the first Kanak enterprises in Thio (see Pitoiset 2002; Le Meur et al. 2012). So their legitimacy as 'political-economic' intermediaries was based on their entrepreneurial expertise and (above all) their interpersonal political skills, rather than their customary authority, which was either weak or disputed. Nor did their position as 'mediators' in such a conflict entail a position of neutrality (see Banks 2008).

The second group consisted of the 'youth'. This was a somewhat fluid category that involved a generational positioning of juniors against elders and a degree of political stigmatisation of 'young people' as being essentially 'unruly'. They emerged as a group in the conflict of 1996 through an association for the unemployed (association des chômeurs), which strongly supported the demand for local recruitment but found itself gradually ousted from the negotiations by the elders representing the customary authorities.

Other groups were either completely absent from the conflict, as in the case of the trade unions, or largely so, as in the case of the political parties. The absence of the trade unions confirms that this was not a labour-related conflict, even though some of the actors were union members, and despite the demands made in relation to recruitment and subcontracting. ${ }^{13}$ As for the marginal role of the political parties, it may be noted that support from the separatists who dominated the local authority was counterbalanced by the discursive definition of the conflict as a 'conflict of the customary people'. Furthermore, despite the fact that the conflict took place in the wake of the process of provincialisation established by the MatignonOudinot Agreements, the authorities of South Province were not involved in the process. ${ }^{14}$

13 In the same year, the dominant trade union of the time, SOENC, formed an alliance with the customary people of the Xârâcùù area in a dispute with the Société Minière du Sud Pacifique and a group of small mining companies (petits mineurs). It should also be noted that SLN made tactical use of 'trade union sources' when it suggested that the Thio blockade put the jobs of the workers at the Doniambo nickel processing plant temporarily at risk (Hervieu 1996).

14 The same absence would be observed in the conflict between the local population and multinational mining company in the neighbouring commune of Yaté a few years later (see Horowitz 2012). North Province took a backseat position during the negotiation of the agreement between SLN and the river clans in the mining area of Tiébaghi, but later intervened in the establishment of the public-private partnership created to manage the local subcontracting arrangement. This point has been confirmed by the former head of the SLN office in Tiébaghi, who negotiated that agreement, as well as the 2008 agreement between SLN, the commune of Thio and South Province (René Féré, interview, 20 February 2012). 
The absence of the provincial authorities can be interpreted in several different ways that are not mutually exclusive. First, the provincial administration was still recently formed and underdeveloped. Second, responsibility for mining was only really devolved to the provinces with the passage of the Organic Law of 1999, and even then was subject to de facto control by the territorial Direction de l'Industrie, des Mines et de l'Énergie de la Nouvelle-Calédonie (see GoNC 2009). Third, the majority of provincial politicians were opposed to independence, so had no sympathy with the concerns of a pro-independence commune. And, finally, the local protagonists themselves wanted to localise the conflict, which gave the central state the possibility of assuming a custodial role in the process.

\section{Localisation of the Conflict and Redefinition of Social and Political Affiliations}

It should be emphasised here that the tension at the root of the conflict was the local version of a more general dispute, which was expressed in the political sequence of events extending from les événements to the MatignonOudinot Agreements and (ultimately) to the Nouméa Agreement.

The historical perspective points to a series of events characterised by the deepening, extension and coalescence of local disputes, which, for many people, centred on the environmental damage caused by SLN's poorly monitored mining activities — uncontrolled dumping, river silting, floods, the displacement and resettlement of certain tribes (Saint-Philippo I and Ouroué, for example) —and regulated by bilateral agreements between SLN and the affected persons. It should also be noted that some of the more serious conflicts made a deep impression, based among other things on the violence and repression involved, and had a significant impact. These included the N'Goye conflict in 1978, conflict around the Koindé sawmills (in the neighbouring commune of La Foa) in 1981, and that in Kouaré (on the other side of the central mountain range, but still in Thio) in 1982-83, which had both environmental and economic dimensions, since it involved forest resources and employment opportunities. And shortly before the conflict described here, on 3 February 1996, there was the list of grievances compiled by the customary area council of Xârâcùù, which contained the same types of demands but on a broader scale than those made in the present case. The Xârâcùù customary council demanded 
compensation for Kanaks from the tribes living in the coastal zone from Mara Cape (in Canala) to the left bank of the Kakoué River (in Thio), the transfer of the mining licences to the customary authorities, and the transfer of land downstream of the mines to the customary landowning clans (Huillet 1996a).

At the same time, it is important to note the national context, which was characterised in the period 1995-96 by the negotiation of the follow-up to the Matignon-Oudinot Agreements. The FLNKS placed the issue of mining at the centre of the negotiations, demanding a 'strong gesture' on the part of the state, and a 'mining precondition' for continuation of the debate. It was this process that culminated in the Bercy Agreement signed on 1 February 1998 (before the Nouméa Agreement of 5 May 1998), which involved an exchange of mining concessions between SLN and the Société Minière du Sud Pacifique and the promise to build a smelter in North Province (see David et al. 2016; also Chapter 2, this volume).

Interviews conducted with two of Thio's political leaders produced agreement on two points. ${ }^{15}$ The first, paradoxically, was that mining itself was not an issue in les événements in Thio, despite the burning down of the SLN offices in Thio Mission and the occupation of the company's residential quarters. At the same time, however, the leaders insisted that this battle was their battle, this was the story of Thio, and it was not influenced by national arguments or slogans. This desire to separate and localise the struggle should be related to the emphasis placed on the role of the 'customary people' as protagonists. As Charles Moindou put it in a newspaper interview:

It has nothing to do [with the mining precondition]. Our movement is independent of politics. The customary people were the ones who took the decisions ... From '84 to '88, SLN negotiated with the customary people. Why did it stop doing this? (Huillet 1996a)

This very common discourse concerning localisation and separation may be interpreted as denoting a concern for the recognition of a Kanak capacity for action, or agency, which is very often denied to them in (white) New Caledonian statements, especially when these refer to the 'insurrection' of 1984-85, when the town was occupied by separatists. According

15 The leaders in question were François Burck, a native of Thio and president of the Caledonian Union until 1996 (interviews, 17 June and 25 August 2011) and Louis Mapéri, the PALIKA member who was mayor of Thio from 1986 to 2001 (interviews, 22 June and 24 August 2011). 
to widespread discourses among non-Kanak people, the relationships between the communities in Thio were supposedly good, and the factors or actors that came to disrupt them originated from elsewhere, partly in the person of separatist leaders like Eloi Machoro, who came from neighbouring Nakéty, but also because the separatists had the backing of the French socialist government from 1981 to 1986 (Roger Galliot, interview, 21 June 2011). ${ }^{16}$ SLN actually did look for Kanak mediators to help restart its production lines and restore its relationship with the local population at the time of the 'insurrection'. One of them was Camillo Ipéré, who has been working for SLN since 1970, and invested his customary and unionist skills in the task of restoring a minimal level of confidence (interviews, 15 July and 25 September 2008), but was hardly a neutral mediator, given his role as a UPM militant and active participant in the pro-independence struggle.

The other side of this localisation is constituted by the rhetoric of custom. The discursive framing of the conflict as a 'conflict of the customary people' enables the elimination of two forms of internal division. The first of these is that of party affiliation: despite the fact that they enjoyed strong customary legitimacy, the two 'big' chiefs and some of the 'small' chiefs in the area belonged to the 'loyalist' Rassemblement pour la Calédonie dans la République. The second harks back to the pre-colonial or early colonial period, especially the war of 1878 , when the clans of the central mountain range (mainly Owi and Koua) took the side of the insurgents in opposition to those of the lower valley of Thio (e.g. Toura, a chiefly clan of that area) (Dousset-Leenhardt 1976; Le Meur 2013). This touches on a paradox of the administrative chieftaincy, for when reference was made to the 'customary people' in 1996, what was in fact intended was the administrative chiefs who were signatories to the agreement signed with SLN, and the partly alien (colonial) origins of their own status enabled the relegation of the old lines of division to the background (Louis Mapéri, interview, 24 August 2011). However, land claims and allocations had revived these divisions in the context of the land reform launched in 1978.

This discursive framing presented a form of indigeneity that is in some ways 'pre-indigenous' from the point of view of the United Nations Declaration on the Rights of Indigenous Peoples (see Demmer 2007;

16 This theme of 'betrayal' by the metropolitan state is a recurrent feature of the New Caledonian interpretation of the events, as revealed in interviews I conducted with M. Fels (a former SLN employee), G. Santacroce (an elderly farmer), and C. Bull in 2010 and 2011. 
Levacher 2016; also Chapters 6 and 9, this volume). At the same time, it enabled the affirmation of a desire to regain control over natural resources and 'traditional' hierarchical principles, which sometimes ran 'counter' to the demands of the youth and pro-independence political parties who were at the forefront during les événements. As a result, the social question was in some sense put on hold, even though it might have been expected to occupy a strategic position in a conflict between local Kanak people and the major industrial enterprise and source of employment in the area. An alternative interpretation, which would be consistent with the theory of the reaffirmation of traditional hierarchical principles, is that the social question was not really put on hold, but was reformulated within a 'Kanak cultural framework' that was mindful of the hierarchies based on antecedence and seniority.

This takes us to the strictly socioeconomic dimensions of the negotiations. With respect to subcontracting, it was possible to observe a shift between the original grievances and the concluding agreement in terms of a greater insistence on local employment. However, there was never any question of supporting the creation of a local subcontracting company, and this reluctance is difficult to explain, given the prevailing dependence on companies with headquarters elsewhere. The Nouméan companies were simply asked to establish offices in Thio. Local employment in the strict sense of 'recruitment' constituted the first point of the agreement:

SLN undertakes to recruit in the next four years at least 16 young people (males and females), with or without qualifications, from the tribes of Thio. SLN undertakes to provide theoretical and practical on-thejob training in Thio for those without qualifications. Moreover, SLN undertakes to recruit three dockers within a period of six months, the first from September 1996.

The question of local employment was specifically raised by the association of the unemployed and, despite the fact that members of the association sometimes felt that they were being excluded from the negotiating table by their elders, results were achieved on this issue and were sustained through the establishment of a local recruitment monitoring committee. ${ }^{17}$ The intergenerational dimension of conflicts that are not necessarily organised around this particular topic has been observed in several other cases in Thio, including those associated with les événements.

17 There were some differences of opinion in this point (Ithupane Tiéoué, interview, 26 November 2010). 
Apart from its intergenerational component, the question of local employment is by definition a 'local' matter. The history of mining in New Caledonia involved a 'nickel boom' in the period 1967-72, followed by a period of decline in the later 1970s (Freyss 1995). Many Kanaks moved to Thio at the time to work in the mines or for the subcontractors, and a good number were employed by companies of French origin. Some of them settled there permanently, married, and eventually became involved in local associations or militant movements. Prior to that, a large number of Kanaks from the Loyalty Islands, in particular Lifou and Ouvéa, had come to work for SLN. These workers inhabited an encampment beside the Plateau mine up to the 1970s, and later lived in the SLN housing estates near the wharf at Pawani. The Association des Kanak de la Grande Terre et des Îles emerged from these migratory movements. This 'ethnonational' association, initially led by pro-independence militants, later evolved into a neighbourhood association, the Association du Botaméré, which took its name from the sugarloaf-shaped mountain that looms over the Thio Mission estate. Both the association and its militant leaders, like Pierre Ayawa, ${ }^{18}$ remained very much in the background during the conflict of 1996. The end of the nickel boom had given rise to certain tensions between the Kanaks who were and were not natives of Thio.

At the same time, the promotion of employment and local entrepreneurship followed a logic of intertribal equity at the level of the commune of Thio. The objective was to balance the distribution of the mining revenues between the different tribes, even if the tribal entity-an administrative unit of colonial origin-is sometimes circumvented by a logic based on networks and alliances. This was the case in the choice of the new manager of SOMIKAT to replace Amédée Tiéoué, who resigned several years after the conflict, and was stigmatised as a 'foreigner' despite the fact that his grandfather had been a resident of Thio, and despite his role as both entrepreneur and official spokesman during the conflict itself. ${ }^{19}$ The new manager came from Nakéty in the neighbouring commune of Canala (see Chapter 4, this volume; also Figure 2.1), but his alliances meant that he could represent the tribe of Ouindo, which is based in Thio.

18 A native of Ponérihouen, Pierre Ayawa came to work for SLN in Thio in 1959 and has remained there since (interview, 7 October 2010).

19 He was known as 'Lifou' after the birthplace of his paternal great-great grandfather, though his clan originally came from the area of Poindimié on the north-east coast. 
Hence, in the long term and, more specifically, through the conflict and agreement of 1996, it is possible to observe a process of reconfiguration of local citizenship, as has been the case in other mining situations. However, this was unlike the case of Lihir in Papua New Guinea (Bainton 2009; also Chapter 11, this volume), where the struggle over access to mining revenues triggered the construction of a local apparatus based on kinship, and hence with strong ethnic connotations. In Thio, it was more the issue of residency and communal affiliation that came to the fore, possibly because the racial ideological space was already occupied by the 'metaconflict' of settler colonialism, and since a considerable number of nonKanak Caledonians had left the area in the period 1984-88, the residential administrative unit of the tribe then achieved greater prominence in public debate. In line with what has already been said about the role of the administrative chieftaincy, this also enabled the circumvention of certain potential dividing lines within the local community.

\section{The Localised Globalisation of the Conflict}

The local appropriation of the conflict went hand in hand with a desire to 'globalise' it from the perspective of the issues and actors. Following Latour (2005: 173ff), this process can be understood in terms of a tension between three complementary aims: (1) to 'localise the global' by situating the latter as a form of the local characterised by a greater density of connections with other sites, and not by a position of superiority; (2) to 'redistribute the local' by showing how it is generated through a series of mediation and translation processes generating the intervention of exterior elements or agents; and (3) to 'connect the [local and global] sites' by means of measurement, classification, categorisation and standardisation procedures.

The objective here was, first and foremost, to get beyond the confrontation with SLN, which meant getting out of the mining enclave: 'SLN, the state, the provinces, and the territory each have their part to play'. The argument played out on several levels. First, it was a way of denouncing the past and present collusions between SLN and the territorial administration. It should also be seen as a way of restating the point that the scope of the conflict was not limited to the labour question within the boundaries controlled by the company. As an interviewed customary representative said: 
Thio has been exploited for 100 years with consequences for the environment, the displacement of communities, the problems of pollution and supply of drinking water (Huillet 1996a).

Finally, the objective was tactical: it was also a matter of seeking alliances. Hence, the environmental argument, which had been deployed for a long time by the Kanaks of Thio, as in the case of the N'Goye conflict of 1978, was taken up again by the head of the subdivision, Jean-Jacques Arlié, who raised the question of compensation when he asserted that 'the customary people are right'. While SLN supported the establishment of what it called an 'economic interest group' (groupement d'intérêt économique) with the task of combating pollution, the company refused to accept responsibility for a century of negative impacts on the environment, and preferred to pass the buck to the state. ${ }^{20}$ While pollution of the environment could be seen as a mode of appropriation in its own right (Le Meur 2010), SLN also deployed the environmental argument in a technical register in the land negotiations: the lands being claimed by local people were not actually required for mining, but they would act as a buffer against the damage associated with the activity.

The politics of land was central. As Charles Moindou was quoted as saying: 'This country must be restored to the landowners' (Huillet 1996a). In this regard, the localised conflict of 1996 is certainly part of the long trajectory of the 'meta-conflict' of settler colonialism, updated by demands for independence and land reform. The agreement of 1996 has several clauses dealing directly with land, concerning the Baie de la Mission residential development and claims over Koua, N'Goye and other land areas. These cases were to be dealt with by land allocations in the years that followed. However, the demand made by Charles Moindou referred to a different 'layer' of land-that is, not the legal one dealt with through statutory claims, acquisitions and allocations, ${ }^{21}$ but the deeper, historical and identity-based layer that calls for a response in terms of the recognition of Kanak antecedence, indigeneity and equal dignity (see Honneth 2000). In this regard, the conflict of 1996 constituted a turning point as it was situated in the logic of the land reform that was in full swing by the 1990 s, while entirely prefiguring this demand for recognition without

20 Jean-Michel Valois, the director of the company's mining operations, was quoted as saying that ' $[\mathrm{t}]$ his problem is enormous but it is up to the state to take responsibility for it' (Huillet 1996b).

21 The status of reserves, reserve extensions, clan-based transfers and the entities known as groupements de droit particulier local ('local groups with special rights') would be transformed by the provisions on customary lands in the Organic Law of 1999. 
necessarily involving any claims for the allocation of specific areas of land. ${ }^{22}$ This demand would arise in several subsequent conflicts and agreements that were not confined to the mining sector, but lay at the root of other large-scale economic projects (Le Meur and Mennesson 2012; Le Meur et al. 2013).

Although the conflict of 1996 manifested a tendency to publicise local disputes more widely, as well as the increasingly complex politics of the mining arena, it was still characterised by a localised framework that had not yet been influenced by the global discourses that did not come to prominence in New Caledonia until the next decade. As previously indicated, there was no explicit mention of 'indigenous rights' in the sense defined by the United Nations, but this did not hinder the emergence of a discourse on identity, antecedence and local citizenship. Likewise, environmental non-governmental organisations had no part to play in the conflict, but this did not mean that environmental issues were absent from the conflict. There were no lawyers on the horizon, and that may be related to the presence of a centralised power represented by the souspréfecture (subdivision), expressing a political-administrative logic rather than one based on legalistic forms of conflict management. ${ }^{23}$ SLN had not yet woken up to the idea of corporate social responsibility, and sustainable development had not yet emerged as the conceptual mediator of divergent interests (Sourisseau et al. 2015). The very brief preamble to the 1996 agreement confirms these absences, but in some respects, they are also hollow presences:

In consideration of the claims expressed by the councils of the two districts of Thio of 25 July 1996, in consideration of the responses provided by SLN, not wishing to further penalise the economic and social climate of the commune, mindful of the need to provide the population of this commune with a long-term development project through the management of natural resources, the following has been agreed.

22 The land reform process, which was launched in 1978 and continued in various institutional forms up to the 2000s, was based on the acquisition of areas of private land by a public agency and their redistribution in the legal form of customary land to Kanak collectives (tribes, clans or groups of clans) based on criteria that combined the logics of proof (historical group legitimacies) and negotiation (current land requirements) (Le Meur 2011).

23 This may be contrasted with the negotiation of the agreement negotiated for the Grand Sud (Goro) project, which was signed by the customary authorities, the indigenous association called Rhêêbù Nùù, and the Brazilian mining company Vale in 2008 (Horowitz 2012). 


\section{A Turning Point in Local Mining Governance?}

Twenty years have passed since the agreement of 1996, a period that gives us the distance required, first, to ascertain whether it has been complied with and had any effect and, second, to evaluate the extent to which it really was a turning point, or 'bifurcation' (Mahoney 2000), in the history of mining governance in Thio.

With regard to the first question, despite the non-binding character of the agreement, it cannot be denied that its various points have been translated into concrete action, albeit at varying speeds. The measure that took longest to implement was the granting of the mining licence to SOMIKAT. More than ten years passed before the local Kanak mining company was formally established in 2007. Priority was given to the question of local employment, and the committee established to monitor the implementation of the agreement functioned for around ten years.

The question of subcontracting leads to the second question. In this regard, the undertakings in the 1996 agreement were ultimately exceeded. Several local subcontractors were established and, in some cases, replaced well-established Nouméan companies. One such example is the local security company (APST) that was established in 2007 by Alcide Tiéoué, the brother of Amédée Tiéoué, after the latter had fallen out with the management of the Nouméan company that had previously dominated the local market for security services. ${ }^{24}$ Several of the local subcontracting companies established after 1996 opted for a logic of intertribal equity, but were also partly owned or operated by Wallisian, Indonesian and 'European' elements of the population. One of them was even called the Société de Développement des Ethnies Réunies- the Company for the Development of United Ethnic Groups. Others, like those owned by members of the Moindou family, adopted a more individual and/or familial strategy, thereby risking the veiled criticism of some relatives, but not losing sight of this issue in their recruitment of personnel. In all cases, irrespective of the actors involved, the local dynamics exceeded the point reached by local people's views and demands in 1996.

24 Amédée had been that company's branch manager in Thio, which was one of the entrepreneurial roles he had played during the conflict. 
During the APST episode, SLN sided with Alcide Tiéoué and supported his enterprise, very probably out of concern to keep the social peace. So did things change completely? As Ithupane Tiéoué, former secretary to the mayor of Thio, reminds us: 'With SLN, you always have to fight to get something' (interview, 26 November 2010). The case of the tribe of Ouroué, whose history of environmental damage and displacement is closely associated with mining, further illuminates this point. Having obtained an agreement similar to that of 1996, also following a conflict, their leaders had to 'increase the pressure again' for the agreement to be implemented, even to the extent that new negotiations had to be held and a new text put on the table in 2007. Not insignificant in this regard is the fact that Narcisse Mapéri, the 'small chief' of this tribe, wears a range of different hats: as a prominent member of the Union Syndicale des Travailleurs Kanak et des Exploités (USTKE), political party member (Parti Travailliste), and as the first president of the Comité Autochtone de Gestion des Ressources Naturelles (CAUGERN). ${ }^{25}$

The transformation of mining governance, inspired in part by the conflict and agreement of 1996, is obvious, and is located in the reconfiguration of the relationships between SLN, the commune and the customary authorities. SLN gradually withdrew from functions that did not have a direct economic significance and that it had long performed by acting as a substitute for the state (Le Meur 2009). Local networks and infrastructure were 'communalised', and the company's housing schemes were privatised. The tripartite agreement between SLN, the commune and South Province, which was signed in 2008, further consolidated this trend. ${ }^{26}$ The fact that this agreement marked the entry of the province into the political process, and the relative marginalisation of the customary representatives, may be seen as a result of the electoral victory of the anti-separatist Avenir Ensemble ('Future Together') political party, which formed as a result of a split in the loyalist block, and which was representative at the time of a more 'autonomist' vision of New Caledonia's destiny. ${ }^{27}$

25 CAUGERN was established in Thio in 2005. If it has a lasting political influence in the commune, that influence has been largely 'subterranean' (Narcisse Mapéri, interview, 2 October 2013).

26 This was the precursor of other agreements of the same nature with North Province that were signed in Poya and Koumac in August 2011.

27 This agreement was also far less localised than that of 1996 (or that of 2004 in Tiébaghi), and also reflected a distinctly 'urban' perspective (René Féré, interview, 20 February 2012). 
The mining governance regime that was developed in Thio after 'the events' is placed under the constantly evoked and constantly rejected horizon of the 'post-nickel era'-primarily by SLN playing on the possible end of mining to calm down social movements, but also by other actors, especially the pro-independence mayors who have constantly striven to outline a post-mine future for Thio. This mining governance regime is characterised both by the mutual repositioning of SLN and the town hall, against a background of frequently difficult relationships ${ }^{28}$ and by transformations in the customary world. The latter changes have arisen both in respect of land, with the growing importance of the demand for recognition without a direct link to claims for land redistribution (as seen earlier), and in respect of the chieftaincy, with the emergence of a new generation of younger chiefs who may have had careers as entrepreneurs. ${ }^{29}$

The conflict of 1996 was structured by the tension between localisation (of situations, conflicts and arrangements) and globalisation (of the reference frameworks, arenas and discourses). Its emblematic nature as a turning point in mining governance should be appreciated on two different levels that reflect this tension. We have seen how, even if it is clear from a local perspective that this conflict constituted a turning point in terms of the scope of the mechanisms it triggered, the assessment of it should still be qualified. Viewed from a wider national perspective, and in the historical context featuring the Matignon-Oudinot and Nouméa agreements, the conflict of 1996 may be viewed retrospectively as the harbinger of a transformation of the mining policy domains, both from the discursive point of view, as in the qualification of the 'pre-indigenous conflict' or the 'pre-sustainable development' preamble to the agreement itself, but also in terms of the actor configuration. The way in which land issues and customary issues were combined in the framework of a renewed politics of recognition was also new.

28 The difficulties were documented in interviews with the current (post-2014) mayor, Jean-Patrick Toura, and his predecessors, Thierry Song (2005-14), Albert Moindou (2001-05), Louis Mapéri (1985-2001) and Roger Galliot (1971-85).

29 'The time when the Kanaks watched the trucks rolling past has gone,' as M. Boéhé, the mayor of Houailou, another east coast mining commune, said in relation to the youth movements in his commune which opposed the pollution caused by SLN (Huillet 1996b). 


\section{Final Remarks in the Light of Recent Events}

To advance the analysis further, it is necessary to develop the comparative work initiated in the context of the research program on mining governance (e.g. Le Meur et al. 2012; Grochain 2013), and to shift the focus to other regional situations that are not exclusively associated with mining. For example, in New Zealand, a form of Maori entrepreneurship has emerged in a context characterised by the recognition of biculturalism, political-tribal reorganisation and neoliberal ideology (Rata 2000). The case of Papua New Guinea is also interesting in this respect, with the role (and shortcomings) of development forums, in which the local impacts and benefits of mining projects must be negotiated in advance (Filer 2008), and with the development of local entrepreneurship in the mining sector (Bainton and Macintyre 2013), which in many ways resembles the dynamics observed in New Caledonia.

Recent local developments in New Caledonia are also revealing, especially the chain of confrontations triggered in Thio by heavy rains and environmental damage in 2013. The ensuing mobilisation-with a mine blockade reminiscent of the 1996 conflict-encountered other sequences of events: one was the local implementation of mine site regulations stipulated by the 2009 mining code; another was the exploration campaign that several mining companies wished to launch on the 'forgotten coast'south of Thio and north of Yaté-where mining operations had ceased 30 years previously in another climate of conflict. These interlinked events confirm the turning point hypothesis in terms of a more complex mining arena with proliferating and recombining discursive repertoires (Le Meur 2015a, 2015b). The 2013 conflict, with its focus on mining impacts, actually pushed companies into acting as honest corporate (and local) citizens. It represented at once a continuation of the 1996 dynamicswith local people trying to regain control over their resources, territories and lives_-and a major shift from away from the conflit des coutumiers, as the 2013 mobilisation adopted an explicitly transethnic stance, including Thio residents of European and Polynesian descent who played no part in the 1996 conflict. This inclusive strategy has not prevented communal leaders-some of them CAUGERN members ${ }^{30}$ —from making use of

30 This point is based on interviews with two CAUGERN members - the previously mentioned Narcisse Mapéri, USTKE member and former chief of the Ouroué tribe (2 October 2013), and JeanGuy M'bouéri, former customary senator and leader of the association created in the wake of the 2013 conflict (4 October 2013 and 17 September 2014). 
the indigenous toolbox, for instance by invoking the principle of 'free, prior and informed consent' (Szablowski 2010). At the same time, the two-year mining ban on the 'forgotten coast' declared by Thio and Yaté customary authorities and indigenous organisations in 2014, after a series of meetings among local people and with mining companies, has followed a different pathway rooted in the discourses of clanship and indigeneity. However, these collective actions all display a strong sense of local identity and express the multilayered nature of citizenship and sovereignty (Joyce 2013). By the same token, they also question the boundaries of the firm and the intricacies of corporate and local governance.

\section{References}

Allen, M.G., 2013. 'Melanesia's Violent Environments: Towards a Political Ecology of Conflict in the Western Pacific.' Geoforum 44: 152-161. doi.org/10.1016/j.geoforum.2012.09.015

_ 2017. 'Islands, Extraction and Violence: Mining and the Politics of Scale in Island Melanesia.' Political Geography 57: 81-90. doi.org/ 10.1016/j.polgeo.2016.12.004

Bainton, N.A., 2009. 'Keeping the Network out of View: Mining, Distinctions and Exclusion in Melanesia.' Oceania 79: 18-33. doi.org/ 10.1002/j.1834-4461.2009.tb00048.x

Bainton, N.A. and M. Macintyre, 2013. "“My Land, My Work”: Business Development and Large-Scale Mining in Papua New Guinea.' In F. McCormack and K. Barclay (eds), Engaging with Capitalism: Cases from Oceania. Bingley (UK): Emerald Group Publishing (Research in Economic Anthropology 33). doi.org/10.1108/s01901281(2013)0000033008

Banks, G., 2008. 'Understanding "Resource" Conflicts in Papua New Guinea.' Asia-Pacific Viewpoint 49: 23-34. doi.org/10.1111/j.14678373.2008.00358.x

Dauphiné, J., 1987. Chronologie Foncière et Agricole de la NouvelleCalédonie, 1853-1903. Paris: L'Harmattan. 
David, C., Sourisseau, J.-M., Gorohouna, S., Le Meur, P.-Y., 2016. 'De Matignon à la Consultation sur l'Indépendance. Une Trajectoire Politique et Institutionnelle Originale.' In S. Bouard, J.-M. Sourisseau, V. Geronimi, S. Blaise and L. Ro’i (eds), La Nouvelle-Calédonie Face à Son Destin: Quel Bilan à la Veille de la Consultation sur la Pleine Souveraineté. Paris: Karthala.

Demmer, C., 2007. 'Autochtonie, Nickel et Environnement: Une Nouvelle Stratégie Kanake.' Vacarme 39: 43-48. doi.org/10.3917/ vaca.039.0043

Dousset-Leenhardt, R., 1976. Terre Natale, Terre d'Exil. Paris: Editions Maisonneuve \& Larose.

Filer, C., 1997. 'Compensation, Rent and Power in Papua New Guinea.' In S. Toft (ed.), Compensation for Resource Development in Papua New Guinea. Boroko (PNG): Law Reform Commission (Monograph 6). Canberra: The Australian National University, National Centre for Development Studies (Pacific Policy Paper 24).

__ 2008. 'Development Forum in Papua New Guinea: Upsides and Downsides.' Journal of Energy \& Natural Resources Law 26: 120-150. doi.org/10.1080/02646811.2008.11435180

Freyss, J., 1995. Economie Assistée et Changement Social en NouvelleCalédonie. Paris: Presses Universitaires de France.

GoNC (Government of New Caledonia), 2009. Le Schéma de Mise en Valeur des Richesses Minières de la Nouvelle-Calédonie. Nouméa: Direction de l'Industrie, des Mines et de l'Énergie.

Grochain, S., 2013. Les Dynamiques Sociétales du Projet Koniambo. Nouméa: Editions IAC.

Hagberg, S., 1998. Between Peace and Justice: Dispute Settlement between Karaboro Agriculturalists and Fulbe Agro-Pastoralists in Burkina Faso. Stockholm: Almqvist \& Wiksell (Uppsala Studies in Cultural Anthropology 25).

Hervieu, P., 1996. 'À Thio, les Tribus Pourraient Lever les Barrages Aujourd'hui.' Les Nouvelles Calédoniennes, 30 July.

Honneth, A., 2000 [1992]. La Lutte pour la Reconnaissance. Paris: Editions du Cerf. 
Horowitz, L., 2012. 'Translation Alignment: Actor-Network Theory, Resistance, and the Power Dynamics of Alliance in New Caledonia.' Antipode 44: 806-827. doi.org/10.1111/j.1467-8330.2011.00926.x

Huillet, F., 1996a. 'Thio: Les Contumiers Bloquent la SLN.' Les Nouvelles Calédoniennes, 26 July.

—_ 1996b. 'Tensions sur les Mines.' Les Nouvelles Calédoniennes, 27 July.

Joyce, R., 2013. Competing Sovereignties. London: Routledge.

Latour, B., 2005. Reassembling the Social: An Introduction to Actor-Network Theory. Oxford: Oxford University Press.

Le Meur, P.-Y., 2009. 'Opérateurs Miniers, Gouvernementalité et Politique des Ressources à Thio, Nouvelle-Calédonie.' Paper presented to the Pacific Science Intercongress, Papeete, 3-6 March.

— , 2010. 'La Terre en Nouvelle-Calédonie: Pollution, Appartenance et Propriété Intellectuelle.' Multitudes 41: 91-98. doi.org/10.3917/ mult.041.0091

_ 2011 . 'Politique et Savoirs Fonciers en Nouvelle-Calédonie: Retour sur une Expérience d'Anthropologie Appliquée.' Journal de la Société des Océanistes 132: 93-108.

—, 2013. 'Locality, Mobility and Governmentality in Colonial/ Postcolonial New Caledonia: The Case of the Kouaré Tribe (xûâ Xârâgwii), Thio (Cöö).' Oceania 83: 130-146. doi.org/10.1002/ ocea.5009

_ 2015a. 'Making Peace with the Mining Past? The Politics of Value and Citizenship in Thio, New Caledonia.' Paper presented to the 10th European Society for Oceanists Conference, Brussels, 24-27 June.

- 2015b. 'Anthropology and the Mining Arena in New Caledonia: Issues and Positionalities.' Anthropological Forum 25: 405-427. doi.org/10.1080/00664677.2015.1073141

Le Meur, P.-Y., S. Grochain, M. Kowasch and D. Poithily, 2012. 'La SousTraitance Comme Interface: Rente Minière, Contrôle des Ressources et Arènes Locales en Nouvelle-Calédonie.' Nouméa: CNRT Nickel, Programme Gouvernance Minière (Document de Travail 10). 
Le Meur, P.-Y., L. Horowitz and T. Mennesson, 2013. "“Horizontal” and "Vertical" Diffusion: The Cumulative Influence of Impact and Benefit Agreements (IBAs) on Mining Policy-Production in New Caledonia.' Resources Policy 38: 648-656.

Le Meur, P.-Y. and T. Mennesson, 2012. 'Accords Locaux, Logique Coutumière et Production des Politiques de Développement en Nouvelle-Calédonie.' Revue Juridique, Politique et Économique de Nouvelle-Calédonie 19: 44-51.

Letté, M., 2009. 'Débordements Industriels dans la Cité et Histoire de Leurs Conflits aux XIXe et XXe Siècles.' Documents pour l'Histoire des Techniques 17: 163-173.

Levacher, C., 2016. De la Terre à la Mine? Les Chemins de l'Autochtonie en Nouvelle-Calédonie. Paris: École des Hautes Études en Sciences Sociales (PhD thesis).

Mahoney, J., 2000. 'Path Dependence in Historical Sociology.' Theory and Society 29: 507-548. doi.org/10.1023/A:1007113830879

Merle, I., 1998. 'La Construction d'un Droit Foncier Colonial: De la Propriété Collective à la Constitution des Réserves en NouvelleCalédonie.' Enquête 7: 97-126.

__ 2004. 'De la "Légalisation" de la Violence en Contexte Colonial: Le Régime de l'Indigénat en Question.' Politix 17(66): 137-162. doi.org/10.3406/polix.2004.1019

Pitoiset, A., 2002. L'Actionnariat Populaire en Province Nord de la NouvelleCalédonie: Société de Profit dans une Société de Partage. Nouméa: Université de Nouvelle-Calédonie.

Rata, E., 2000. A Political Economy of Neotribal Capitalism. Lanham (MD): Lexington Books.

Regan, A.J., 1998. 'Causes and Course of the Bougainville Conflict.' Journal of Pacific History 33: 269-285. doi.org/10.1080/00223349808572878

__ 2014. 'Bougainville: Large-Scale Mining and Risks of Conflict Recurrence.' Security Challenges 10(2): 71-96. 
Sourisseau, J.-M., S. Bouard, C. Gaillard, P.-Y. Le Meur, T. Mennesson and G. Pestaña, 2015. 'Entre Neutralisation et Requalification: Les Limites de la Diffusion du Référentiel du Développement Durable en Nouvelle-Calédonie.' In S. Blaise, C. David and V. David (eds), Le Développement Durable en Océanie: Vers une Éthique Nouvelle? Marseille: Presses Universitaires de Provence.

Szablowski, D., 2010. 'Operationalizing Free, Prior and Informed Consent in the Extractive Industry Sector? Examining the Challenges of a Negotiated Model of Justice.' Canadian Journal of Development Studies 30: 111-130.

Turner, V., 1957. Schism and Continuity in an African Society. Manchester: Manchester University Press.

Winslow, D., 1993. 'Mining and the Environment in New Caledonia: The Case of Thio.' In M. Howard (ed.), Asia's Environmental Crisis. Boulder (CO): Westview Press. 
This text is taken from Large-scale Mines and Local-level Politics: Between New Caledonia and Papua New Guinea, edited by Colin Filer and Pierre-Yves Le Meur, published 2017 by ANU Press, The Australian National University, Canberra, Australia. 